\title{
Analisis Faktor-Faktor Yang Berhubungan dengan Kekambuhan pada Skizoprenia
}

\author{
Dewi Eka Putri ${ }^{\mathrm{a}}$, Feri Fernandes ${ }^{\mathrm{a}}$ \\ ${ }^{a}$ Fakultas Keperawatan, Universitas Andalas, Padang, 25163, Indonesia \\ email korepondensi: dewiekaputri@nrs.unand.ac.id
}

\begin{abstract}
In Indonesia, the incidence of schizophrenia has increased every year. Conditions for an increase in schizophrenia cases also occur in West Sumatra. One problem in treating schizophrenia is recurrence. Many factors cause recurrence in people with schizophrenia (ODS). This study aims to analyze the factors associated with recurrence in schizophrenia patients in West Sumatra. Analytic research design with a cross-sectional study approach. The study sample was 145 patients with schizophrenia and their families who visited the outpatient clinic HB RSJ. Saanin Padang. Data collection using family support questionnaires, Level of Expression Emotion, family attitudes, and medication adherence. The results showed a median recurrence score of 1.00, which meant that the patient had a recurrence, average family support of 74.27, an average family attitude of 33.21, an average medication adherence of 9.92 as well as and an average level of emotional expression was 140. There was an association found meaningful between recurrence with medication adherence and the level of emotional expression of the family. Still, there is no relationship between recurrence with family support and family attitudes. It expected that nurses will help patients improve medication adherence and train families to reduce the level of emotional expression in treating patients with schizophrenia.
\end{abstract}

Keywords: recurrence, schizophrenia, family support

\begin{abstract}
Abstrak
Di Indonesia insiden Skizofrenia setiap tahunnya mengalami peningkatan. Kondisi peningkatan kasus skizofrenia juga terjadi di Sumatera Barat. Salah satu masalah dalam penanganan skizofrenia adalah kekambuhan. Banyak faktor yang menyebabkan terjadinya kekambuhan pada orang dengan skizofrenia (ODS). Penelitian ini bertujuan menganalisis faktor-faktor yang berhubungan dengan kekambuhan pada ODS di Sumatera Barat. Desain penelitian analitik dengan pendekatan cross sectional study. Sampel penelitian adalah 145 ODS dan keluarganya yang berkunjung ke poli rawat jalan RSJ HB. Saanin Padang. Pengumpulan data menggunakan kuesioner dukungan keluarga, Level of Expression Emotion, sikap keluarga dan kepatuhan minum obat. Hasil penelitian menunjukkan skor median kekambuhan adalah 1.00 yang berarti ODS mengalami kekambuhan, rata-rata dukungan keluarga 74.27, rata-rata sikap keluarga 33.21, rata-rata kepatuhan minum obat 9.92 dan median level ekspresi emosi adalah 140. Ditemukan ada hubungan yang bermakna antara kekambuhan dengan kepatuhan minum obat dan level ekspresi emosi keluarga namun tidak ada hubungan kekambuhan dengan dukungan keluarga dan sikap keluarga. Diharapkan kepada perawat untuk membantu ODS dalam meningkatkan kepatuhan minum obat dan melatih keluarga untuk dapat menurunkan tingkat ekspresi emosi dalam merawat ODS dengan mengelola stres.
\end{abstract}

Kata kunci : kekambuhan, skizofrenia, dukungan keluarga 


\section{PENDAHULUAN}

Ganggguan jiwa merupakan masalah global yang dihadapi dunia saat ini. Gangguan jiwa dapat ditemui disetiap tahap perkembangan manusia. Gangguan jiwa merupakan suatu keadaan dimana terjadinya defisit pengetahuan dan perkembangan, adanya pola perilaku yang maladaptif, serta ketidakmampuan merespon stresor sehingga terjadinya penolakan terhadap lingkungan (Stuart, 2013).

Di dunia ada sekitar 450 juta orang mengalami gangguan jiwa (WHO, 2012). World Health Organization (WHO) memperkirakan angka gangguan jiwa akan berkembang hingga 25\% pada tahun 2030.

Indonesia merupakan salah satu negara di dunia yang memiliki angka gangguan jiwa berat yang relatif tinggi. Kondisi ini juga dialami oleh penduduk di Sumatera Barat, berdasarkan hasil Riskesdas tahun 2013, prevalensi gangguan jiwa berat di Sumatera Barat 1,9 permil. Angka tersebut menunjukkan bahwa penderita gangguan jiwa berat di Sumbar masih berada diatas angka kejadian gangguan jiwa berat nasional yakni sebesar 1,7 permil.

Gangguan jiwa berat yang banyak ditemukan adalah skizofrenia. Pada tahun 2014 sekitar 21 juta orang penduduk dunia menderita skizofrenia (WHO,2014). Di Indonesia fenomena skizofrenia setiap tahunnya selalu mengalami peningkatan (Laeli, dkk, 2017).

Skizofrenia merupakan gangguan mental dimana penderitanya akan mengalami gangguan dalam proses berfikir, emosi, bahasa, perilaku, persepsi dan kesadaran (WHO, 2012a, 2016). Skizofrenia adalah dimana seseorang tidak mampu mengenali realitas atau memiliki tilikan (insigth) yang buruk (Riskesdas, 2013). Ada sekitar 99\% skizofrenia di RS Jiwa di Indonesia adalah penderita skizofrenia (Amelia, 2013). Penderita skizofrenia disebut dengan Orang Dengan Skizofrenia (ODS).

Salah satu masalah dalam penanganan skizofrenia adalah kekambuhan. Kekambuhan adalah berulangnya kondisi sakit atau memburuknya gejala penyakit gangguan jiwa. Kekambuhan yang dialami oleh ODS dapat membahayakan diri klien sendiri, keluarga, dan masyarakat. Penelitian di Hongkong menemukan bahwa dari 93 ODS masing-masing memiliki potensi Kekambuhan $21 \%, 33 \%$, dan $40 \%$ pada tahun pertama, kedua, dan ketiga (Amelia, 2013). Adapun faktor-faktor yang dapat menyebabkan Kekambuhan adalah ketidakpatuhan terhadap obat antipsikotik, stres/depresi dan penyalahgunaan zat (Olivares, 2012). Kekambuhan pada satu tahun setelah terdiagnosa ODS dialami oleh 60-70\% ODS yang tidak mendapatkan terapi medikasi (Wardhani, 2009). Sementara faktor risiko Kekambuhan menurut Sariah (2014) tidak patuh terhadap pengobatan antipsikotik, dukungan keluarga yang buruk, peristiwa kehidupan yang penuh tekanan dan penggunaan narkoba. Tingkat pengetahuan keluarga yang rendah menyebabkan frekuensi Kekambuhan penderita ODS semakin bertambah setelah dikontrol oleh variabel sikap, dukungan, ekspresi emosi keluarga, dan kepatuhan minum obat. Pada penelitian ini peneliti menganalisis faktorfaktor diatas sebagai faktor yang berhubungan dengan terjadinya kekambuhan pada ODS (Zahnia, 2016).

\section{METODE}

Penelitian ini menggunakan desain analytic dengan pendekatan cross sectional study. Populasi penelitian ini adalah seluruh ODS yang datang ke poli klinik rawat jalan RSJ Prof. HB. Saanin Padang dan keluarga 
yang langsung merawat ODS, pengambilan sampel dalam penelitian ini mengunakan teknik non probability sampling dengan pendekatan purposive sampling. Jumlah sampel dalam penelitian ini ada 145 orang ODS dengan skzofrenia dan keluarga yang berperan sebagai caregiver. Penelitian ini dilakukan dari bulan Maret sampai November 2018 di RSJ Prof. HB. Saanin Padang.

Pengumpulan data menggunakan 5 kuesioner yaitu kuesioner kekambuhan untuk mengukur kekambuhan, dukungan keluarga untuk mengukur dukungan kekuarga, Level of Expression Emosi untuk mengukur level ekpresi emosi, kepatuhan minum obat untuk mengukur kepatuhan dan sikap keluarga untuk mengukursikap keluarga terhadap ODS. Data diolah dengan program komputerisasi untuk melihat hubungan antar variabel dengan menggunakan uji pearson product moment dan uji Spearman. Peneliti telah melakukan uji etik sebelum penelitian ini dilakukan.

\section{HASIL}

Adapun karakteristik responden secara umum dalam penelitian ini adalah $67.6 \%$ responden berjenis kelamin laki-laki, $44.1 \%$ berpendidikan SMA, $53.8 \%$ berstatus belum menikah, $79.3 \%$ lama pengobatannya lebih dari 1 tahun, $81.4 \%$ tidak merasa terganggu dengan efek samping obat, $89.7 \%$ menggunakan obat dengan tepat, $61.4 \%$ pernah dirawat satu kali, $93.8 \%$ tidak menggunakan Napza dan $96.6 \%$ menggunakan asuransi kesehatan untuk pengobatan.
Tabel 1. Rerata Kekambuhan, Kepatuhan Minum Obat, Dukungan Keluarga, Sikap Keluarga dan Ekspresi Emosi Keluarga Pada ODS Di RSJ HB. Saanin Padang $(n=145)$

\begin{tabular}{|l|l|l|l|l|}
\hline Variabel & Rerata & $\begin{array}{l}\text { Min - } \\
\text { Max }\end{array}$ & SD & CI 95\% \\
\hline $\begin{array}{l}\text { Kekambuh } \\
\text { an }\end{array}$ & 1 & $0-1$ & - & $\begin{array}{l}0,83- \\
0,94\end{array}$ \\
\hline $\begin{array}{l}\text { Kepatuhan } \\
\text { minum } \\
\text { obat }\end{array}$ & 9,92 & $0-19$ & $\begin{array}{l}5,1 \\
0\end{array}$ & $9.1-10,7$ \\
\hline $\begin{array}{l}\text { Dukungan } \\
\text { Keluarga }\end{array}$ & 74,27 & $15-78$ & 9,8 & $72,6-75,8$ \\
\hline $\begin{array}{l}\text { Sikap } \\
\text { Keluarga }\end{array}$ & 33,01 & $24-40$ & 3,7 & $32,4-33,6$ \\
& & 8 & \\
\hline $\begin{array}{l}\text { Ekspresi } \\
\text { Emosi } \\
\text { Keluarga }\end{array}$ & 143,9 & $117-$ & - & $\begin{array}{l}141,8- \\
146,02\end{array}$ \\
\hline
\end{tabular}

Tabel 1 menunjukkan bahwa nilai median kekambuhan pada ODS adalah 1,00 dengan skor minimum 0 dan skor maksimum 1. Ini berarti ODS mengalami Kekambuhan. Rata-rata dukungan keluarga pada ODS adalah 74.27 dengan skor minimum 15 dan skor maksimum 78. Standar deviasinya 9.821. Nilai rata-rata sikap keluarga pada ODS adalah 33.01 dengan skor minimum 24 dan skor maksimum 40. Standar deviasinya 3.783. Rata-rata kepatuhan minum obat pada ODS adalah 9.92 dengan skor minimum 0 dan skor maksimum 19. Standar deviasinya 5,102. Nilai median Ekpresi Emosi Keluarga pada ODS adalah 143.90 dengan skor minimum 117 dan skor maksimum 179. 
Tabel 2. Hubungan Kepatuhan Minum Obat, Dukungan Keluarga, Sikap Keluarga, Ekpresi Emosi Keluarga dengan Kekambuhan pada ODS di RSJ HB. Saanin Padang $(\mathrm{n}=145)$

\begin{tabular}{cccc}
\hline \multirow{2}{*}{ Variabel } & \multicolumn{3}{c}{ Kekambuhan } \\
\cline { 2 - 4 } & $\mathrm{r}$ & $\mathrm{r}^{2}$ & $\mathrm{p}$ Value \\
\hline $\begin{array}{c}\text { Kepatuhan } \\
\text { minum } \\
\text { obat }\end{array}$ & $-0,225$ & 0,05 & 0,007 \\
\hline $\begin{array}{c}\text { Dukungan } \\
\text { Keluarga }\end{array}$ & $-0,017$ & 0,0003 & 0,843 \\
\hline $\begin{array}{c}\text { Sikap } \\
\text { Keluarga }\end{array}$ & $-0,131$ & 0,0172 & 0,115 \\
\hline $\begin{array}{c}\text { Ekspresi } \\
\text { Emosi } \\
\text { Keluarga }\end{array}$ & 0,159 & 0,02 & 0,05 \\
& & & \\
\end{tabular}

Tabel 2. menunjukkan bahwa adanya hubungan yang bermakna antara kepatuhan minum obat dengan kekambuhan yang dialami oleh ODS dengan nilai $\mathrm{p}=0.007$. Kepatuhan minum obat dengan Kekambuhan memiliki hubungan negatif dengan kekuatan hubungan yang lemah $(r=-0.225)$, artinya kepatuhan minum obat dengan Kekambuhan memiliki hubungan yang berbanding terbalik. Semakin meningkat kepatuhan minum obat maka kekambuhan akan semakin rendah begitu pula sebaliknya. Disamping itu juga bisa dilihat bahwa kepatuhan minum obat mempengaruhi kekambuhan sebesar $5.1 \%$.

Tidak Ada hubungan yang bermakna antara dukungan keluarga dengan kekambuhan yang dialami oleh ODS dengan nilai $\mathrm{p}=0.843$. Antara dukungan keluarga dengan kekambuhan memiliki hubungan negatif dengan kekuatan hubungan yang lemah $(r=-0.017)$. Dari penelitian ini diketahui dukungan keluarga mempengaruhi kekambuhan hanya sebesar $0,03 \%$.

Tidak adanya hubungan yang bermakna antara sikap keluarga dengan kekambuhan yang dialami oleh ODS dengan nilai $\mathrm{p}=0.115$. Antara sikap keluarga dengan kekambuhan memiliki hubungan negatif dengan kekuatan hubungan yang lemah $(\mathrm{r}=$ $0.131)$. Dari penelitian ini diketahui sikap keluarga mempengaruhi kekambuhan sebesar $1,72 \%$.

Ada hubungan yang bermakna antara ekpresi emosi keluarga dengan kekambuhan yang dialami oleh ODS dengan nilai $\mathrm{p}=0.05$. Antara ekspresi emosi dengan kekambuhan memiliki hubungan positif dengan kekuatan hubungan yang lemah $(r=0,159)$, artinya ekpresi emosi dengan kekambuhan memiliki hubungan yang berbanding lurus. Semakin tinggi ekspresi emosi maka kekambuhan akan semakin tinggi begitu pula sebaliknya. Disamping itu juga bisa dilihat bahwa ekspresi emosi mempengaruhi kekambuhan sebesar $2,5 \%$.

\section{PEMBAHASAN}

Hasil penelitian ini menemukan ada hubungan yang signifikan antara kekambuhan dengan kepatuhan minum obat. Pada penelitian ini ODS mengalami kekambuhan rendah yaitu $1 \mathrm{x}$ per tahun. Sementara kepatuhan minum obatnya ratarata cenderung rendah. Hal ini berarti cukup banyak ODS yang tidak patuh minum obat sehingga kemungkinan kekambuhan masih terus ditemukan. Penelitian lain menemukan kekambuhan pada satu tahun setelah terdiagnosa ODS dialami oleh 60-70\% ODS yang tidak mendapatkan terapi medikasi (Wardhani, 2009; Goff et al, 2010). Banyak ODS segera mengalami kekambuhan setelah melakukan pengurangan dan penghentian pengobatan (Emsley,2013).

Pada ODS ditemukan tanda dan gejala positif dan negatif (Struart, 2016). ODS dengan gejala positif (terutama pada waham dan manik) lebih sulit untuk patuh terhadap pengobatan karena merasa dipaksa dan takut diracuni (Fleischacker, dkk, 2003) 
sedangkan ODS dengan gejala negatif memiliki tingkat kepatuhan yang lebih tinggi. Hal ini bisa dijelaskan karena pada ODS ini mengalami kurang motivasi yang mengakibatkan dampak negatif untuk mengikuti program pengobatan, namun disisi lain mereka juga tidak mempunyai energi sehingga hanya mengikuti anjuran dokter dan mengikuti apa yang disarankan.

Pola hidup ODS yang sebagian besar mengkonsumsi nikotin (rokok) dan kafein dapat menghambat efektifitas kerja obat antipsikotik dengan demikian keberhasilan terapi medik tidak mungkin dicapai maksimal (Stuart \& Laraia, 2010). Kondisi kebiasaan ODS mengkonsumsi nikotin dan kopi tersebut membuat efek terapeutik dari obat tidak dirasakannya sehingga menyebabkan ODS tidak patuh terhadap pengobatan.

Hasil penelitian juga diketahui ada hubungan yang signifikan antara ekpresi emosi keluarga dengan kekambuhan walaupun kekuatan hubungannya lemah dan arah yang positif. Ini sejalan dengan hasil penelitian sebelumnya dimana frekuensi kekambuhan ODS bertambah bila tinggal di dalam lingkungan keluarga dengan ekspresi emosi yang kuat (highly expressed emotion) atau gaya afektif negatif secara signifikan lebih sering mengalami kekambuhan dibandingkan dengan yang tinggal dalam lingkungan keluarga dengan ekspresi emosi yang rendah (low expressed emotion) atau gaya afektif yang normal (Kapplan \& saddock, 2010). Dampak kondisi diatas membuat ODS enggan melalukan rehabilitasi, cenderung menarik diri, merahasiakan penyakitnya, persahabatan terputus sehingga tekanan dan stres yang dirasakan ODS semakin meningkat. $80 \%$ terjadinya kekambuhan karena ada hal buruk secara psikososial menimpa ODS seperti di asingkan oleh keluarga, dan masyarakat (Hawari dan Slestari, wardani 2014).
Hasil penelitian ini menemukan tidak ada hubungan yang bermakna antara dukungan keluarga dengan kekambuhan. Penelitian ini menunjukkan bahwa rata-rata dukungan keluarga pada ODS cendrung tinggi. Dukungan keluarga akan menimbulkan ketenangan batin dan perasaan senang dalam diri ODS (Dagun, 2002). Dukungan keluarga diwujudkan dalam bentuk mengawasi kepatuhan klien minum obat dan kontrol ke rumah sakit sehingga sangat membantu dalam perawatan ODS. Namun beberapa penelitian menemukan dukungan keluarga yang rendah, rendahnya dukungan keluarga ini dapat diketahui dari beberapa hasil penelitian seperti, Sariah (2014) menyatakan bahwa ODS dan caregivers merasakan bahwa dukungan keluarga yang buruk. Buruknya dukungan diketahui dari penelitian yang menemukan keluarga dalam merawat ODS di rumah menggunakan ekspresi emosi (marah) yang berlebihan (Amelia, 2013).

Menurut Videbeck (2008), mengungkapkan bahwa meminta serta menerima dukungan ketika ODS membutuhkan merupakan langkah vital dalam proses penyembuhan gangguan jiwa seperti ODS. Walaupun anggota keluarga tidak selalu merupakan sumber positif dalam mendukung kesehatan jiwa.

Penelitian ini juga menemukan tidak ada hubungan sikap keluarga dengan kekambuhan pada ODS. Hasil menunjukkan bahwa sikap keluarga ODS rata-rata berada pada nilai 33.01, ini berarti sikap keluarga terhadap ODS cendrung positif. Keluarga merupakan tempat yang aman dan

damai bagi anggota keluarga untuk istirahat dan pemulihan serta membantu penguasaan terhadap emosi (Friedman, 2010). Sering menjadi bagian penting dalam proses penyembuhan. Sikap yang baik pada keluarga dapat mencegah kekambuhan ODS. 


\section{DAFTAR PUSTAKA}

\section{KESIMPULAN}

1. Orang Dengan ODS di RS. Prof. HB. Saanin Padang rata-rata memiliki kekambuhan yang rendah.

2. Dukungan keluarganya rata-rata cendrung tinggi, Sikap keluarga ratarata cendrung positif, kepatuhan minum obat rata-rata cendrung patuh dan Ekpresi emosi keluarga rata-rata cendrung rendah

3. Ada hubungan yang bermakna antara kepatuhan minum obat dengan kekambuhan, dengan kekuatan hubungan lemah dan arah negatif.

4. Ada hubungan yang bermakna antara level ekspresi emosi keluarga dengan kekambuhan dan kekuatan hubungan lemah dengan arah positif

\section{SARAN}

Diharapkan kepada perawat untuk dapat meningkatkan kepatuhan ODS dalam pengobatan dengan meningkatkan pengetahuan tentang pengobatan dan kesadaran diri dari ODS serta membantu melatih mengelola stress keluarga dalam merawat ODS di rumah

\section{UCAPAN TERIMA KASIH}

Kepada Fakultas Keperawatan dan RS. Prof. HB. Saanin Padang.
Amelia, D. R., \& Anwar, Z. (2013). Kekambuhan Pada Pasien Skizofrenia, 1(1), 53-65.

Depkes. (2014). Stop Stigma dan Diskriminasi terhadap Orang Dengan Gangguan Jiwa (ODGJ).

Friedman, M. M., Bowden, V. R., \& Jones, E. G. (2010). Buku Ajar Keperawatan Keluarga Riset, Teori dan Praktik (Ed 5). Jakarta: EGC : Jakarta.

Hawari, D. 2009. Penyalahgunaan dan Ketergantungan Napza. Balai Penerbitan FKUI, Jakarta.

Riskesdas. (2013). Laporan Hasil Riset Kesehatan Dasar Indonesia Tahun

Sadock, B. J., Sadock, V. A., \& Ruiz, P. (2014). Kaplan \& Sadock's Synopsis of Psychiatry: Behavioral Sciences/Clinical Psychiatry (Ed. 11th). Penyunt. Philadelphia: Wolters Kluwer.

Sariah, A. E., Outwater, A. H., \& Malima, K. I. Y. (2014). Risk and protective factors for Kekambuhane among individuals with schizophrenia: a qualitative study in Dar es Salaam, Tanzania. $B M C$ Psychiatry, $14,240$. https://doi.org/10.1186/s12888-0140240-9

Stuart, G. W. (2013). Prinsip dan Praktik Keperawatan Kesehatan Jiwa (Ed. Indone). Jakarta: Fakultas Keperawatan Indonesia.

Stuart, G. W. (2016). Prinsip dan Praktik Keperawatan Kesehatan Jiwa Stuart. 
NERS: Jurnal Keperawatan, Volume 16, No. 2, Oktober 2020, (Hal. 38-44)

(B. A. Keliat, Ed.) (Ed. Indone). Fakultas Keperawatan Universitas Indonesia.

Wardani, I.Y., Hamid, A.Y., \& Wiarsih,W. (2009). Pengalaman Keluarga Menghadapi Ketidak patuhan Anggota Keluarga Dengan Skizofrenia Dalam Mengikuti Regimen Terapeutik: Pengobatan Tesis FIK UI.

WHO. (2012a). Schizophrenia. Retrieved from www.who.co.id

WHO. (2012b). The word Health Repoth: 2012: Mental Health. Retrieved from www.who.co.id

WHO. (2014). Mental health: a state of wellbeing. Retrieved from http://www.who.int/features/factfiles/ mental_health/en/

WHO. (2016). Schizophrenia. Retrieved from www.who.co.id 